\title{
Spatial Development of Agricultural Land Division throughout the Ages in Villages of the Opoczno County
}

\section{Introduction}

Development of agricultural land division over the centuries in the villages of the Opoczno County resulted in defective spatial structure of the region's rural areas. Numerous factors have influenced today's picture of the countryside in Central Poland. In this article the authors attempt to identify factors which have impacted the present spatial structure of the investigated area. The study was based on registration data acquired from the district geodetic and cartographic documentation centre in Opoczno as well as field research.

\section{Location of the Investigated Area}

The Opoczno County is situated between two rivers, the Vistula and the Pilica. Opoczno, the district capital, is located at a distance of $100 \mathrm{~km}$ from Warsaw and 90 km from Łódź (Fig. 1).

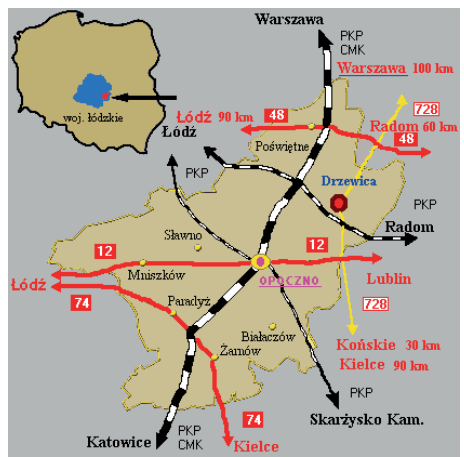

Fig. 1. Location of the Opoczno County

Source: http://archiwalna.drzewica.pl, accessed on 20.03.2015

* Jan Kochanowski University in Kielce, Kielce, Poland

** Rzeszów School of Engineering and Economics, Institute of Cadastral Surveying and Geodetic Engineering, Rzeszów, Poland 
Opoczno is located along the Drzewiczka River, a right-bank tributary of the Pilica. The Opoczno County comprises an area within the Opoczyńskie Hills, which run along the north-western border of the Kielce Upland, and comprise areas encircled by the large arch of the Pilica, from Przedbórz to Smardzewice and from Końskie as far as Drzewica. This is an area of approx. $1460 \mathrm{~km}^{2}$. In the east the county borders on the Gielniowski Hump, in the south-east it adjoins the Suchedniów Plateau, and in the south the Łopuszańskie Hills as well as the Przedborsko-Małogoskie Range. The northern and western boundary of the region is also a border of the Małopolska Upland and the Central Polish Lowlands. Opoczno is located in the north-western outskirts of the Kielce-Sandomierz Upland, i.e. between the Małopolska Upland and the Mazovian Lowland [1].

\section{History of Settlements in the Opoczno Region}

Human settlements appeared here as early as the $10-11^{\text {th }}$ century, mainly in the areas with terrain and natural conditions convenient for this purpose. Other favourable factors included important traffic routes, rivers and fertile soils. These conditions enabled establishment of such settlements as: Opoczno, Drzewica, Odrzywół, Inowłódz. A trade route passing through Drzewica, Odrzywół and northward via Nowe Miasto was part of the Amber Road from Cracow to Warsaw and further to the Baltic Sea. Another important route ran through Opoczno and Inowłódz. This location contributed to the development of these places and the growing wealth of their populations. The factors of vital importance for the development of civilization included: easy access to water from the rivers Pilica and Drzewiczka as well as the soils which yielded good crops for consumption by the local people and for trade [2].

Villages situated away from traffic routes and rivers did not have such convenient conditions for growth. The lands were owned by families with a status of nobility; they established large landed estates, were endowed with privileges and had authority over peasants. This system survived until the mid-19 $9^{\text {th }}$ century.

In the following centuries the Opoczno region witnessed a systematic development of new settlements which were established as colonies. Over 70 perpetual colonies were founded during 1812-1862. These were mainly established within large and medium-size landed estates, in areas cultivated by land owners, in areas formerly occupied by serfs, and in deforested areas (as many as 60\%). Farming lands designated for parcelling out for the new colonies were frequently of poor quality; these were plots of fields and forests, pastures, thickets, wilderness and wasteland. Most frequently the colonies comprised an area of 200-300 morgens and settlers would receive farms of 15-30 morgens. Names of colonies most commonly were derived from the first names of owners or members of their families, e.g. Emilianów Emilia, Stanisławów - Stanisław, Wandzinów - Wanda, or, less frequently, from their last names or names of coats of arms. Within the Opoczno County in 1859 there 
were 310 rent based settlements, 1220 rent and tribute based settlements as well as 5626 tribute based settlements [2].

\section{Legal Property Rights}

Property rights in the area reflected the conditions which were predominant over the ages throughout Poland.

From the times of early settlements, in Poland and in the area of Opoczno there were two types of agricultural operations: those maintained by landowners and peasants. Landed estates comprised the most fertile soils, while peasants were most often left to manage poor soils, unprofitable for manor owners. Peasants faced double load of work. They cultivated their own plots and had to pay tribute to the lord of the manor by working in his estate. The latter duty was varied, depending on the times and circumstances. It ranged from a few days in a year to a few days per week (even 5 days a week). Another important aspect, leading to overpopulation of rural areas, was the limited personal freedom of peasants. During the reign of King Casimir the Great, only two peasant families were allowed to leave the village in a given year. In the 1400s, the times of King John Albert, only one person from a peasant family was allowed to leave the village. If permitted by the lord of the manor, only one son of peasants from a given village could go to town to get education or learn a craft. This situation continued during the times of foreign authority. Changes occurred only in the 1860s, as a result of peasants' resistance which contributed to a greater awareness of problems faced by the rural population in Poland [2].

The rebellion of Polish peasants against serfdom kept growing and gained impetus after the agrarian reform of 3 March 1861, introduced in the Russian Empire. The reform in fact did not apply to peasants living in Congress Poland; this led to strong protests, especially in early April 1861. In May 1861 peasant riots spread to 1076 villages. As a result the authorities introduced the so-called redemption payments. In autumn of 1861 large number of villages (95\%) adopted the redemption payment system. Other related developments included the ordinance of statutory rent, issued on 5 June 1862 which continued the process of replacing serfdom with redemption payment. These provisions were only implemented after the outbreak of the January Uprising in 1863. Ordinances related to granting property rights were issued on 2 March 1864. After that peasants gained ownership of approx. 7.8 million morgens of land; including the plots owned by townsmen, the figure amounted to 8.3 million [3].

Imperial ordinance granted peasants with the property rights for plots of land cultivated by them. They no longer had to work for the lord of the manor; instead they were required to pay land value tax to the state treasury. Yet, rural population continued to vary in status; there were farmers, semi-farmers, croft holders, cottage holders and shed holders. Importantly, peasants were now allowed to move away. 
Some set off "for bread", seeking jobs in towns or abroad. The fact that peasants gained property rights contributed to a change in their worldview and mentality. This social group, oppressed for ages by Polish nobility, gradually changed its subservient attitude to their overlords. Emancipated, the peasant became the master of his land. He also desired more independence and education, which would enable him e.g. to make better use and retain the ownership of the land. Peasants were driven by the need (or even desire) to own as much land as possible; that led to "craving for land". Yet, divided between family members (bequests to children), peasants' farms were more and more fragmented. Due to this the average size of peasants' farms kept decreasing [2]; that adversely affected financial situation of rural populations, frequently resulting in poverty and even deprivation, particularly during periods preceding the new harvest.

\section{Agrarian Reforms in the Period from 1918 to 1950}

After Poland regained independence in 1918 challenges related to agriculture continued to exist. They resulted from the defective system of bondage and subordination. Two thirds of all farms in Poland in those days were small, comprising no more than 5 ha; their profits were lower than those yielded by large farming estates. In addition to the small farms there were also large landed estates, accounting for approx. $1 \%$ of the total number, and these comprised nearly half of the agricultural land of the country. Agrarian problems became more pronounced in the latter half of the 1800s and in the early 1920s. These were still caused by peasants' poverty, which contributed to the so-called "craving for land". Agrarian issues were the main political and economy related problems in Poland after its liberation, and were particularly pronounced in the areas formerly subjected to Austrian and Russian authority, where peasants rebelled against their masters. In the times of the Second Republic there was an awareness of the need for agrarian reform because of the growing peasant movement. The government announced an intention to nationalize large and medium size landed estates to be further transferred, by the state, to smallholders and landless peasants [4].

Under pressure from peasants' parties the Legislative Parliament passed a resolution on 10 July 1919 concerning the rules of implementing an agrarian reform [5]. The agrarian reform act was adopted on 15 July 1920 [6]. Accordingly, for the purpose of implementing the agrarian reform the following categories of land were defined: land owned by the state, purchased by the state from land owners, estates owned by the ruling dynasties of the countries formerly in control of Poland, the so-called mortua manus estates (owned by churches and monasteries) and estates owned by various public institutions. It was also determined that the Main Authority for Landed Estates was entitled to buy out land and excess plots in accordance with defined criteria. The rules and prices were defined for enforced buyout and 
parcelling out. The act stipulated: a plan of parcelling, potential buyers, buyout fund and other rules [6]. Unfortunately, due to the noncompliance of the act with the Constitution, only 19,000 ha of land were parcelled out in 1919-1920.

On 28 December 1925 the parliament passed another agrarian act [7]. It was most favourable for large landowners. The process of parcelling out was very slow and by 1939 it was only completed at the level of 58\%. In 1933 the agrarian act was amended. The total of 2.6 million ha of land was parcelled out during 1919-1939.

Agrarian reforms were interrupted by World War II. A new decree on agrarian reform was issued on 6 September 1944 by the Polish Committee of National Liberation [8]. The document specified the types of farming land subject to the reform, the results of expropriation without damages, or the level of damages or compensation paid to owners of estates subject to parcelling out [9]. The parliament passed the act of 20 March 1950 on nationalization of landed estates owned by the Church and religious communities and on establishing the Church Fund [10] and following the decree of 12 December 1944 some forests became a property of the State Treasury [11].

\section{Analysis of Spatial Structure of Rural Areas in the Opoczno County}

As a result of developments related to settlements in the area of Opoczno, the county comprises 216 land register units. In terms of administration they belong to 8 communes; this is illustrated by data in Table 1 and by Figure 2 .

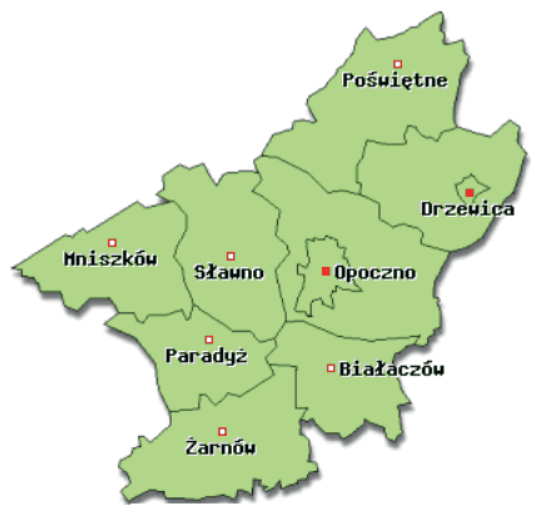

Fig. 2. Spatial distribution of the communes in the Opoczno County Source: www.archiwum.opocznopowiat.pl, accessed on 20.03.2015.

The largest is the Commune of Opoczno, which comprises 36 villages with a total area of $19,064.0$ ha, accounting for $18.3 \%$ of the total county area. The second largest is the Commune of Żarnów. It comprises 43 villages, and a total area of $14,106.0$ ha, i.e. $13.6 \%$ of the total county area. The next one in terms of size is the 
Commune of Poświętne, with 17 villages, and an area of 14,081.0 ha, accounting for $13.5 \%$ of the total area of the county. It is followed by the Commune of Sławno, located west of Opoczno, which comprises 34 villages and an area of 12,931.0 ha. i.e. $12.4 \%$ of the total county area. The areas of the next 3 communes: Mniszków, Drzewica and Białaczów are in the range from $11.0 \%$ to $11.9 \%$ of the total area of the county. The smallest Commune of Paradyż comprises 26 villages and a total area of $8,139.0$ ha, i.e. $7.8 \%$ of the total area of the Opoczno County.

Table 1. Spatial structure of the communes in the Opoczno County

\begin{tabular}{|c|l|c|c|c|c||}
\hline \multirow{2}{*}{ No. } & \multirow{2}{*}{$\begin{array}{c}\text { Name of } \\
\text { commune }\end{array}$} & \multicolumn{2}{|c|}{ Commune villages } & \multicolumn{2}{|c|}{$\begin{array}{c}\text { Total area of the } \\
\text { commune }\end{array}$} \\
\cline { 4 - 7 } & & number & {$[\%]$} & {$[\mathrm{ha}]$} & {$[\%]$} \\
\hline \hline 1 & Białaczów & 14 & 6.5 & $11,463.0$ & 11.0 \\
\hline 2 & Drzewica & 17 & 7.9 & $11,819.0$ & 11.4 \\
\hline 3 & Mniszków & 29 & 13.4 & $12,416.0$ & 11.9 \\
\hline 4 & Opoczno & 36 & 16.7 & $19,064.0$ & 18.3 \\
\hline 5 & Paradyż & 26 & 12.0 & $8,139.0$ & 7.8 \\
\hline 6 & Poświętne & 17 & 7.9 & $14,081.0$ & 13.5 \\
\hline 7 & Sławno & 34 & 15.7 & $12,931.0$ & 12.4 \\
\hline 8 & Żarnów & 43 & 19.9 & $14,106.0$ & 13.6 \\
\hline & Total: & 216 & 100.0 & $104,019.0$ & 100.0 \\
\hline
\end{tabular}

\subsection{Population Density in the Relevant Area}

The largest in terms of population is the urban commune of Opoczno, which is inhabited by 35,461 people, i.e. $45.2 \%$ of the total population of the county. This number includes 22,188 residents of the town of Opoczno. With the rate of 186 people per $1 \mathrm{~km}^{2}$ this commune is most densely populated; the second in terms of population is the Commune of Drzewica, with 94 people per $1 \mathrm{~km}^{2}$.

The remaining communes of the Opoczno County are characterized by low population density, ranging from 38 people per $1 \mathrm{~km}^{2}$ in the Commune of Mniszków to 57 people per $1 \mathrm{~km}^{2}$ in the Commune of Stawno (Tab. 2). The findings show that population density in the villages of the Opoczno County is quite low, with an average of 75 people per $1 \mathrm{~km}^{2}$. For comparison, the average population density in the villages of the Brzozów County in the Podkarpackie Province amounts to 124 people per $1 \mathrm{~km}^{2}$, with the rate for Brzozów, the county capital, at the level of 262 people per $1 \mathrm{~km}^{2}[12]$. 
Table 2. Demographic rates in the Opoczno County

\begin{tabular}{|c|l|c|c|c|c|c||}
\hline \multirow{2}{*}{ No. } & \multirow{2}{*}{ Name of commune } & \multicolumn{2}{|c|}{ Commune villages } & \multicolumn{2}{c||}{ Population } & \multirow{2}{*}{$\begin{array}{c}\text { Population } \\
\text { density per } \\
1 \mathrm{~km}^{2}\end{array}$} \\
\cline { 3 - 7 } & number & {$[\%]$} & number & {$[\%]$} & 52 \\
\hline \hline 1 & Białaczów & 14 & 6.5 & 5,952 & 7.6 & 94 \\
\hline 2 & Drzewica & 17 & 7.9 & 11,076 & 14.1 & 38 \\
\hline 3 & Mniszków & 36 & 13.4 & 4,754 & 6.1 & 186 \\
\hline 4 & Opoczno & 26 & 12.0 & 4,434 & 5.7 & 54 \\
\hline 5 & Paradyż & 17 & 7.9 & 3,273 & 4.2 & 23 \\
\hline 6 & Poświętne & 34 & 15.7 & 7342 & 9.4 & 57 \\
\hline 7 & Sławno & 43 & 19.9 & 6,181 & 7.9 & 44 \\
\hline 8 & Żarnów & 216 & 100.0 & 78,473 & 100.0 & 75 \\
\hline
\end{tabular}

\subsection{Structure of Ownership and Land Use in the Opoczno County}

The conducted analyses (Tab. 3) show that, in the villages of the Opoczno County 75,699.0 ha of land belong to owners of individual farms; this accounts for $72.8 \%$ of the total county area. 'State Forests' National Forest Holding owns 19,904.0 ha, i.e. $19.1 \%$ of the total county area. Communal lands constitute $2 \%$, and other lands account for $6.1 \%$ of the total rural area.

Table 3. Legal property rights

\begin{tabular}{|c|l|c|c||}
\hline \multirow{2}{*}{ No. } & \multicolumn{2}{|c|}{ Name of group } & \multicolumn{2}{|c|}{ Area } \\
\cline { 3 - 4 } & & {$[\mathrm{ha}]$} & {$[\%]$} \\
\hline \hline 1 & Land owned by private farms & $75,699.0$ & 72.8 \\
\hline 2 & 'State Forests' National Forest Holding & $19,904.0$ & 19.1 \\
\hline 3 & Communal land & $2,101.0$ & 2.0 \\
\hline 4 & Other land & $6,315.0$ & 6.1 \\
\hline \multicolumn{2}{c}{ Total: } & $104,019.0$ & 100.0 \\
\hline
\end{tabular}


The data in Table 4 show that the county is characterised by a large proportion of agricultural land, which comprises an area of $65,829.0$ ha, i.e. $63.3 \%$ of the total county area. More specifically, arable land comprises an area of 49,559.0 ha, accounting for $47.6 \%$ of the total county area. The region in question is characterised by a large proportion of forests. The findings show that forests comprise an area of $32,509.0$ ha, i.e. $31.3 \%$ of the total county area.

Table 4. Structure of agricultural land

\begin{tabular}{||l|c|c||}
\hline \multirow{2}{*}{\multicolumn{1}{|c|}{ Type of land }} & \multicolumn{2}{c|}{ Area } \\
\cline { 2 - 3 } & 4 [ha] & {$[\%]$} \\
\hline \hline Arable land & 982.0 & 47.6 \\
\hline Orchards & $6,072.0$ & 5.9 \\
\hline Permanent grassland & $6,261.0$ & 6.0 \\
\hline Permanent pastures & $2,427.0$ & 2.3 \\
\hline Built-up agricultural land & 149.0 & 0.1 \\
\hline Areas of ponds & 379.0 & 0.4 \\
\hline Areas of ditches & $65,829.0$ & 63.3 \\
\hline Total agricultural lands: & $32,509.0$ & 31.3 \\
\hline Forests & 583.0 & 0.6 \\
\hline Wooded land & $33,092.0$ & 31.8 \\
\hline Total forests and wooded land & 3749.0 & 3.6 \\
\hline Built-up and developed land & 883.0 & 0.8 \\
\hline Areas of watercourses & 37.0 & 0.0 \\
\hline Ecological sites & 421.0 & 0.4 \\
\hline Wasteland & 8.0 & 0.0 \\
\hline Various areas & $104,019.0$ & 100.0 \\
\hline Total: & & \multicolumn{2}{c|}{} \\
\hline \hline
\end{tabular}

The findings related to the structure of land use show that farming land and forests constitute a majority in the county. Yet, the data presented in Table 5 show varied distribution of the types of land in the specific communes. 
Table 5. Proportion of farming land (FL) and forests in the communes of the Opoczno County

\begin{tabular}{|r|l|c|c|c|c||}
\hline \multirow{2}{*}{ No. } & \multirow{2}{*}{$\begin{array}{c}\text { Name of } \\
\text { commune }\end{array}$} & $\begin{array}{c}\text { Number of } \\
\text { villages in } \\
\text { commune }\end{array}$ & $\begin{array}{c}\text { Total area of } \\
\text { commune [ha] }\end{array}$ & \multicolumn{2}{|c|}{ Including } \\
\cline { 5 - 7 } & & 14 & $11,463.0$ & 53.0 & 37.0 \\
\hline 1 & Białaczów & 17 & $11,819.0$ & 60.0 & 33.0 \\
\hline 2 & Drzewica & 29 & $12,416.0$ & 59.0 & 33.0 \\
\hline 3 & Mniszków & 36 & $19,064.0$ & 69.0 & 19.0 \\
\hline 4 & Opoczno & 26 & $8,139.0$ & 78.0 & 16.0 \\
\hline 5 & Paradyż & 17 & $14,081.0$ & 38.0 & 57.0 \\
\hline 6 & Poświętne & 34 & $12,931.0$ & 76.0 & 15.0 \\
\hline 7 & Sławno & 43 & $14,106.0$ & 70.0 & 22.0 \\
\hline 8 & Żarnów & 216 & $104,019.0$ & - & - \\
\hline
\end{tabular}

The percentage of farming land ranges from $38.0 \%$ in the commune of Poświętne, to $78 \%$ in the commune of Paradyż. Percentage of forests ranges from $15.0 \%$ in the commune of Sławno to $57 \%$ in the commune of Poświętne.

\subsection{Analysis of Land Layouts in the Investigated Area}

Development of settlements in the Opoczno region occurred as a result of establishing new colonies. Each owner received a land of a few morgens, including one large piece of land and a so-called "annex". As a rule, the annex would comprise an area of several ares of land, such as a forest or meadow. The spatial structure of lands in rural areas evolved as a result of an extremely complex process influenced by a diversity of interrelated phenomena. The division of the rural areas was and still is greatly impacted by the form of land ownership. This in turn has depended on a number of factors.

Population density was the primary factor contributing to the changes in the spatial structure of land in the countryside; it was closely related to factors linked with the natural environment as well as structure of economy and production [13]. The statement by Noga aptly explains the state of the spatial land structure in the investigated region. Overpopulation and lack of possibility to migrate resulted in the fact that relatively large farms of 15-30 morgens were constantly divided between family members (all children inherited the land). Due to this the mean size of peasants' farms became lower and lower. 
The consecutive property division led to significant land fragmentation and most importantly, to the resulting ribbon-type patchwork of fields, which is so typical for the region (Fig. 3).

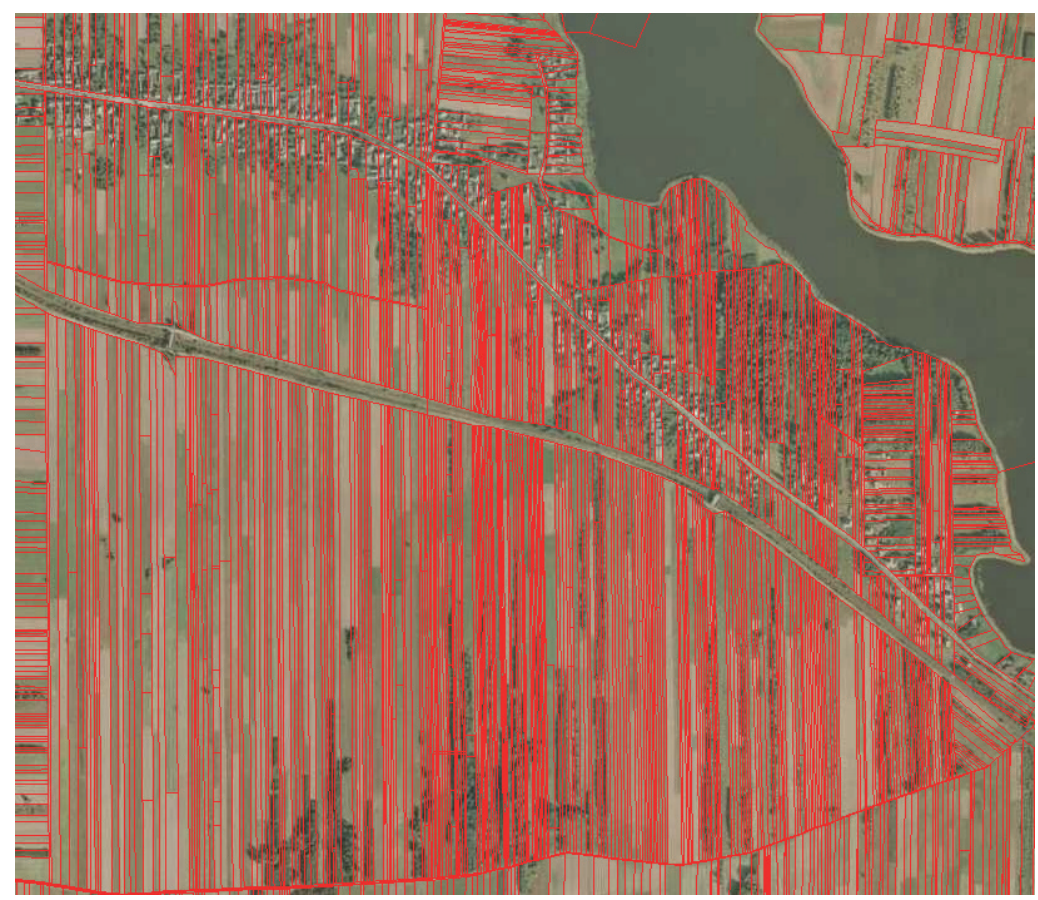

Fig. 3. Part of the village of Strzyżów in the commune of Drzewica Source: www.geoportal.gov.pl, accessed on 25.03.2015

The present findings show that practically the entire area of the county is characterized by the ribbon-type patchwork of land, and plots range in width from $2 \mathrm{~m}$ to several metres, yet the very narrow plots of land are most common. Such defective layout is in fact even more pronounced in areas of private forests, where the width of specific plots does not exceed a few metres (Fig. 4).

Field inspection of a selected farm showed other irregularities. In order to have access to the entire land, this particular owner had to delineate a road through his farm, which is shown in Figure 5. The road is $2.5 \mathrm{~m}$ wide. In total, the plots $(329,330,331)$ are $27 \mathrm{~m}$ wide, and the farm has a length of 1,330 m, including a section of 110 metres, which is fenced and holds the house and farm buildings. Hence, a 2.5 metre wide road has been sectioned off along a distance of 1,220 m, comprising a total area of 0.3050 ha, i.e. $8.5 \%$ of the total land adjoining the buildings. The same situation can be seen in other farms. Therefore, the necessity to section off a road leads to significant loss in the size of the farm. 


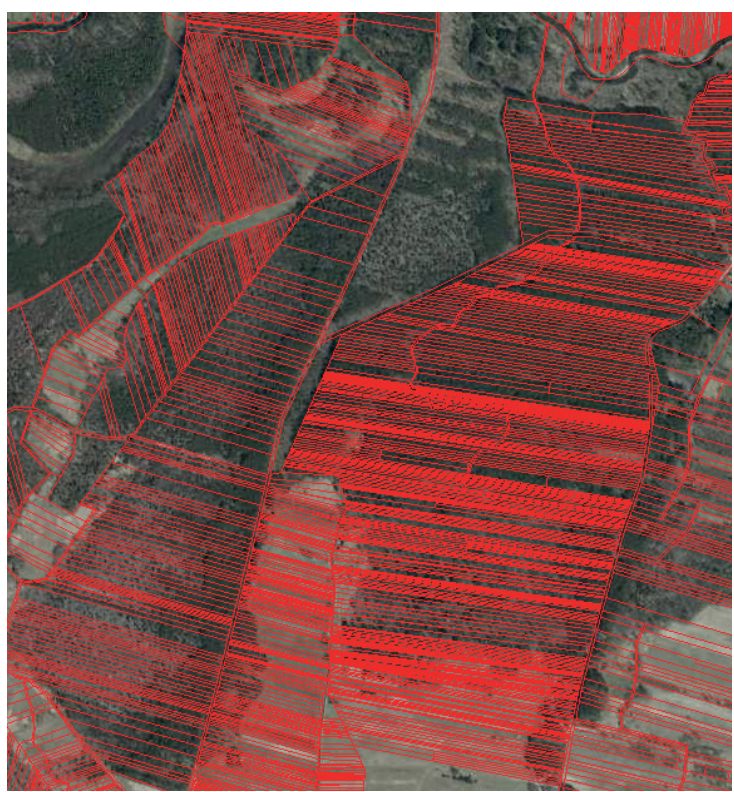

Fig. 4. Part of a forest in the village of Brzustowiec, commune of Drzewica Source: www.geoportal.gov.pl, accessed on 25.03.2015

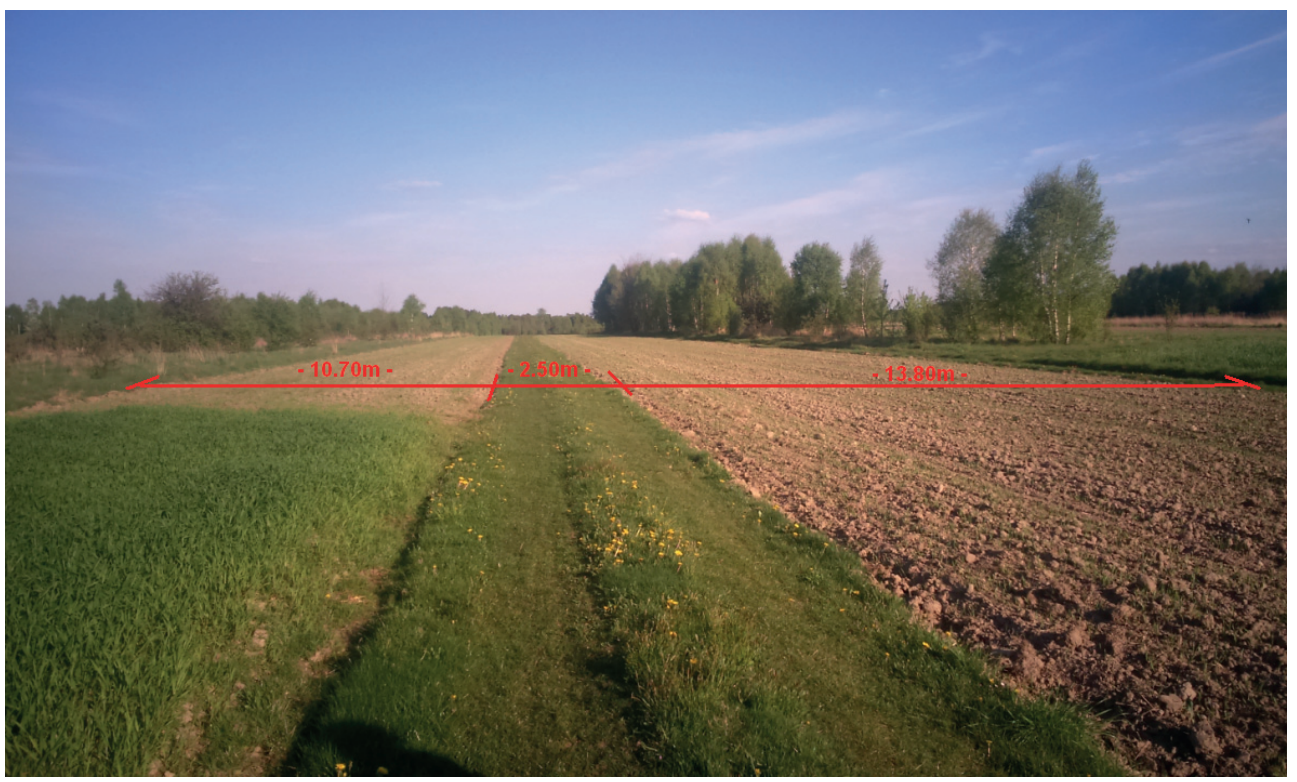

Fig. 5. Area of a farm in the village of Brzustowiec, plots no. 329,330,331 


\section{Conclusions}

The present study has shown that rural areas in central Poland are characterized by high proportion of lands belonging to individual farms. In terms of structure, land property is dominated by agricultural areas, and in particular arable land. Similarly, forests constitute a significant percentage of the area, and their proportional share in specific communes of the Opoczno County is greatly varied. The analysis also shows that the spatial division of land throughout the ages negatively impacted the current spatial structure of rural areas in Central Poland. Overpopulation in the rural areas, as well as lack of possibility for people to migrate to towns resulted in the fact that peasants' farms were more and more fragmented, which in the investigated area, contributed to the development of ribbon-type patchwork of land. The present situation presents great disadvantages and hinders development of agriculture in the region. Therefore, it is necessary to initiate works aimed at consolidation of farming land in the area. Adequately performed land consolidation enables effective organization of farms, also contributing to the conservation of the natural environment. It creates adequate conditions for sustainable and multifunctional development of rural areas by reducing the harmful effects of intensive farming for the natural environment and results in better living and working conditions enjoyed by rural populations.

\section{References}

[1] Żarnowiecki G., Olszewski J.L.: Warunki geograficzno-przyrodnicze Opoczna. [in:] Meducka M. (red.), Opoczno. Studia i szkice z dziejów miasta, Kieleckie Towarzystwo Naukowe, Kielce 2003, pp. 15-30.

[2] Sroka J.: Nasze Brudzewice 1321-2000: monografia. Tomaszów Mazowiecki 2002.

[3] Groniowski K.: Uwłaszczenie chłopów w Polsce: geneza - realizacja - skutki. Wiedz Powszechna, Warszawa 1976.

[4] Kostrowicka I., Landau Z., Tomaszewski J.: Historia gospodarcza Polski XIX i XX wieku. Książka i Wiedza, Warszawa 1978.

[5] Roszkowski W. [pseud. Andrzej Albert]: Najnowsza historia Polski 1914-1993. T. 1, 1914-1945. Świat Książki, Warszawa 1995.

[6] Ustawa z dnia 15 lipca 1920 r. o wykonaniu reformy rolnej [Act on the performance of agrarian reform, dated 15 July 1920]. Dz.U. $1920 \mathrm{nr}$ 70, poz. 462.

[7] Ustawa z dnia 28 grudnia 1925 r. o wykonaniu reformy rolnej [Agrarian Act dated 28 December 1925]. Dz.U. 1926 nr 1, poz. 1.

[8] Dekret Polskiego Komitetu Wyzwolenia Narodowego z dnia 6 września 1944 r. o przeprowadzeniu reformy rolnej [Decree on the agrarian reform implementation, dated 6 September 1944]. Dz.U. 1944 nr 4, poz. 17. 
[9] Słabek H.: Dzieje polskiej reformy rolnej 1944-48. Wiedza Powszechna, Warszawa 1972.

[10] Ustawa z dnia 20 marca 1950 r. o przejęciu przez Państwo dóbr martwej ręki, poręczeniu proboszczom posiadania gospodarstw rolnych i utworzeniu Funduszu Kościelnego [Act on nationalization of mortua manus estates, dated 20 March 1950]. Dz.U. 1950 nr 9, poz. 87.

[11] Suchoń A., Kowalczyk M.: Analiza przepisów dekretu PKWN z 6 września 1944 r. o przeprowadzeniu reformy rolnej wraz z późniejszymi zmianami oraz innych aktów prawnych, na podstawie których nastapiło przejęcie nieruchomości ziemskich i lasów. [in:] Borkowska-Bagieńska E., Szafrański W. (red.), Reformy rolne w Polsce międzywojennej i powojennej, Wydawnictwo Naukowe Uniwersytetu im. Adama Mickiewicza, Poznań 2008, pp. 63-138.

[12] Leń P.: Sposób określenia pilności potrzeb scalenia i wymiany gruntów. Akademia Górniczo-Hutnicza, Kraków 2013 [Ph.D. thesis].

[13] Noga K.: Metodyka programowania i realizacji prac scalenia i wymiany gruntów w ujęciu kompleksowym. Akademia Rolnicza, Kraków 2001. 